Published in final edited form as:

Surg Endosc. 2013 September ; 27(9): 3056-3072. doi:10.1007/s00464-013-2823-9.

\title{
Common Uses and Cited Complications of Energy in Surgery
}

\author{
Ganesh Sankaranarayanan ${ }^{1}$, Rajeswara R. Resapu ${ }^{1}$, Daniel B. Jones ${ }^{2}$, Steven \\ Schwaitzberg ${ }^{3}$, and Suvranu $\mathrm{De}^{1}$ \\ ${ }^{1}$ Center for Modeling, Simulation and Imaging in Medicine, Rensselaer Polytechnic Institute, Troy, \\ NY \\ ${ }^{2}$ Beth Israel Deaconess Medical Center, Harvard Medical School, MA \\ ${ }^{3}$ Cambridge Health Alliance. Cambridge, MA, Harvard Medical School, Boston, MA
}

\begin{abstract}
Background-Instruments that apply energy to cut, coagulate and dissect tissue with minimal bleeding facilitate surgery. The improper use of energy devices may increase patient morbidity and mortality. The current article reviews various energy sources in terms of their common uses and safe practices.
\end{abstract}

Methods-For the purpose of this review, a general search was conducted through NCBI, SpringerLink and Google. Articles describing laparoscopic or minimally invasive surgeries using a single or multiple energy sources are considered, as are the articles comparing various commercial energy devices in laboratory settings. Keywords such as 'laparoscopy', 'energy', 'laser', 'electrosurgery', 'monopolar', 'bipolar', 'harmonic', 'ultrasonic', 'cryosurgery', 'argon beam', 'laser', 'complications', and 'death' were used in the search.

Results and Conclusion-A review of the literature shows that the performance of the energy devices depends upon the type of procedure. There is no consensus as to which device is optimal for a given procedure. The technical skill level of the surgeon and the knowledge about the devices are both important factors in deciding safe outcomes. As new energy devices enter the market increases, surgeons should be aware of their indicated use in laparoscopic, endoscopic and open surgery.

\section{Keywords}

minimally invasive surgery; electrosurgery; ultrasonic; harmonic scalpel; argon beam coagulation; laser; radio frequency ablation; thermal damage; embolism; fire

\section{INTRODUCTION}

The vast majority of surgical procedures performed throughout the world involve the use of some device that applies energy to the tissue for cutting, coagulation, desiccation or fulguration for the destruction or manipulation of the tissue. While various energy sources including electricity, ultrasound, laser, argon gas, microwaves or radiofrequency waves may be used, the fundamental principle involves tissue necrosis and hemostasis by heating. The process of denaturation of tissue begins with the irreversible aggregation of macromolecules

Corresponding Author: Prof. Suvranu De, JEC 2049, Department of Mechanical, Aerospace and Nuclear Engineering, Rensselaer Polytechnic Institute, 110, 8th Street, Troy, NY 12180, Phone: 518-276-6096 Fax: 518-276-6025, des@ rpi.edu.

DISCLOSURE

Drs. Ganesh Sankaranarayanan, Rajeswara Resapu, Daniel B. Jones, Steven Schwaitzberg, and Suvranu De have no conflicts of interest or financial ties to disclose. 
and the unraveling of collagen helices around $60^{\circ} \mathrm{C}$. Protein denaturation occurs between $70^{\circ} \mathrm{C}$ and $80^{\circ} \mathrm{C}$ resulting in coagulation. Further heating to $90^{\circ} \mathrm{C}$ results in dehydration or dessication. Beyond $100^{\circ} \mathrm{C}$, the intercellular water boils, eventually vaporizing the cell allowing tissue cutting. Finally, tissue fulguration or carbonization occurs beyond $200^{\circ} \mathrm{C}[1]$. At present, there is no standardized curriculum for surgeons that address the physics, safe use and complications associated with these devices that promote the best outcomes for patients. In a recent study [2], it was found that many surgeons have knowledge gaps in the safe use of widely used energy-based devices. To address this issue, the Society of American Gastrointestinal and Endoscopic Surgeons (SAGES) has recently initiated the Fundamental Use of Surgical Energy (FUSE) program to develop an educational curriculum that will cover both didactic and hands-on training approaches to the use of energy in interventional procedures in the operating room and endoscopic procedure areas. The goals are to prevent untoward events such as operating room fire, patient injury, surgeon/staff injury as well as promoting optimal use.

The purpose of this paper is to summarize some of the major energy sources used in laparoscopic surgery and discuss their relative advantages and disadvantages.

\section{METHODS}

The review includes a thorough search of literature concerning the physics, applications, success, complications and comparison of various energy sources in surgery. Priority was given to human studies and laparoscopic procedures. However, the studies involving animals (both in vivo and in vitro) and open procedures which were unique and relevant to the assessment of the energy sources were considered. Emphasis was placed on more recent studies covering the latest techniques and studies conducted on live patients in the United States. The keywords used in the search were numerous and the websites such as Medline, PubMed, SpringerLink and Google were extensively covered along with various books published in the field.

\section{Electrosurgery}

Electrosurgery was developed by Dr. William T. Bovie in the 1920s, where a spark gap generator was used to build the first electrosurgery tool, commonly known as RF knife or 'Bovie' [3]. In the 1950's, the first bipolar unit was built by Dr. Leonard Malis, wherein two electrodes were used for gripping and manipulating the tissue.

Mechanism of Electrosurgery-In electrosurgery, heat is generated in the tissue by the flow of radio frequency (RF) electric current unlike electrocautery where the heat is transferred directly from the tool to the tissue. The use of RF current (voltage in the range of 300 to $500 \mathrm{KHz}$ ) eliminates neuromuscular stimulation, which ceases above $100 \mathrm{KHz}$. When the RF electrical energy is made to concentrate in a very small area in the tissue, typically by applying the energy through pointed or hooked tool tips, the resulting high concentration of current flow in a narrow area increases the cellular temperature which leads to various effects on the tissue including, coagulation, dessication or dehydration and carbonization.

The RF energy can be applied to tissue by using either monopolar or bipolar tools. In monopolar electrosurgery, the electrical circuit is completed by the passage of current from the active electrode at the surgical site to the dispersive electrode (or the return electrode) attached to the body of the patient. The active electrode can be of any form (usually a point, hook or a blade) with sharp edges and/or blunt edges. The sharp edges increase the current density (the amount of current per unit area) and used for cutting whereas the blunt edges are used for coagulation. The return electrode is usually a wide pad, attached to the skin of 
the patient, which disperses the heat and safely leads the current out of the body. In bipolar electrosurgery both active and return electrodes are located in the same tool and the electrical circuit is closed by the small area of tissues that are grasped or manipulated by the tool. Bipolar tools are, thus, usually designed as grippers or forceps. Since the current only has to travel short distances in bipolar surgery, the voltage required for the surgery is low. Lower voltage is better for uniform drying of the tissue which minimizes the chance of rebleeding. Thus the bipolar devices are more suitable for coagulation rather than cutting.

The RF energy is applied through specialized electrosurgical generators, which are RF wave form generators with different duty cycles (percentage of time the energy is applied). Different tissue effects such as cutting, coagulation can be achieved by selecting different duty cycles with $100 \%$ duty cycle enables cutting whereas lower duty cycles can be effectively used for coagulation. Though electrosurgical generators produced by each manufacturer are different, they usually provide selections such as pure cutting, coagulation and blended waveforms.

The waveforms with different duty cycles can be used to produce four main effects in electrosurgery namely, cutting, coagulation, desiccation and fulguration. The cutting is achieved by using a continuous waveform (100\% duty cycle) applied through the active electrode of a monopolar electrosurgical tool with a pointed tip. The narrow tip allows for large current concentration and when placed near the tissue but not in contact, generates an arc through which the current rushes to the tissue generating large amount of heat (greater than $100^{\circ} \mathrm{C}$ ) which leads to rapid tissue vaporization and induces cutting. When a blunt instrument tip is used with contact on the tissue, the decreased current concentration due to increased surface area leads to increase in the tissue temperature but not to point of vaporization and creates a coagulum at temperature between 70 to $80^{\circ} \mathrm{C}$ and desiccation at temperature of $90^{\circ} \mathrm{C}$. To perform coagulation or desiccation, a lower duty cycle high voltage waveform is used but can also be performed with $100 \%$ duty cycle lower voltage cutting waveform as well. Finally in fulguration, a lower duty cycle high voltage waveform is applied through the active electrode of a pointed monopolar electrosurgical tool tip in non contact mode close to the tissue. With high voltage and low duty cycle (usually $6 \%$ ), the heat generated by the current flowing through the arc from the tool tip heats the tissues to form coagulum and with repeated application, increases the temperate to $200^{\circ} \mathrm{C}$ or more forming carbonization or fulguration.

The most commonly used electrosurgery devices are listed in Table 1. The bipolar instruments provide compression force in addition to thermal energy, which helps in better sealing of blood vessels and attaining better burst pressures. Thus these instruments seal larger blood vessels as opposed to monopolar devices which are limited to smaller vessels usually less than $2 \mathrm{~mm}$ [4]. The earlier generation of electrosurgical tools did not have temperature control and hence, resulted in thermal injuries. The latest instruments (e.g., Ethicon EndoSurgery's ENSEAL) claim to measure temperature or impedance to provide consistent heating to prevent injuries.

Complications and Recurrences in Electrosurgery-Electrosurgery accounts for 80 $\%$ of all cutting and coagulation in surgeries performed today. According to the Association of periOpertaive Registered Nurses (AORN), there are around 40,000 patient burn cases annually due to faulty electrosurgical devices and in 1999 alone, nearly \$600 million was paid in claims for those injuries [5]. Care should be taken when operating the electrosurgical devices, particularly monopolar devices. The sparking effect at the tool tip may cause an explosion when it comes into contact with inflammable gases that are often used for anesthesia during the operation. Further, the current travelling through the body can interfere with any implanted medical devices such as pacemakers [6] and defibrillators. A metal 
instrument or implant that comes in the way of the current passing through the body may create a different loop causing tissue damage in unwanted regions. Other mechanisms through which injuries can occur during electrosurgery include insulation failure [7], direct and capacitive coupling. Insulation of the electrosurgical tool may break due to repetitive use of the equipment, high intensity of current flowing through the wire and in repeated sterilization process. Burns occur at places of insulation defect and can be fatal especially when the defect is small which leads to high current concentration. Moreover the insulation defect is often very small and will be difficult to detect using the naked eye and an active electrode monitoring system may abate injury [8]. Direct coupling occurs when the active electrode is either intentionally or inadvertently touched by another tool or scope, in which case, energy can be transmitted through the other tool to the tissues. Though in many instances, it is used intentionally, in laparoscopic procedures, it is often dangerous since the view of surrounding organs is limited. Capacitive coupling may occur in a laparoscopic surgery when the tools, tissues and trocars are in close proximity creating capacitance effect (build up of charge between two conductors separated by an insulator). This stored charge may discharge causing unintended tissue damage in the immediate vicinity. If possible, the use of metal and hybrid (with plastic) cannula should be avoided to eliminate injuries. This may be a particular hazard in the emerging technique of single port laparoscopic surgery where all of the instruments are in close proximity. Though the spread of current through the body is eliminated by the use of bipolar electrosurgery, chance of damage to adjacent tissues still exists [9]. Apart from the common laparoscopic complications that arise due to surgical error, the other major complication from electrosurgery is the thermal injuries to adjacent organs. However, the complications can be both intra-operative and postoperative and are specific to the type of procedure performed. Complicating the matter further is that the maximum temperature and thermal spread when using energy based devices varies based on the types of target tissue and the type of energy sources used [10]. Monopolar electrosurgery was shown to have higher temperature and thermal spread [11-13]. Various studies on laparoscopic procedures have shown complications while using monopolar and bipolar electrosurgical instruments that includes conversions, failures, and recurrences [14-19]. There are cases in which death has been reported when using monopolar electrosurgical device [20, 21]. Specifically Agarwal et al. [22] mentioned that the use of an energy source, especially monopolar electrosurgery is the culprit for many of the injuries during laparoscopic cholecystectomy.

Indications and Contraindications of electrosurgery-Electrosurgery has the highest number of thermal injuries, but it still is one of the most popular techniques used in laparoscopy. Out of the two electrosurgical modalities, monopolar electrosurgery causes the most thermal damage but bipolar devices have also shown to produce thermal damage [11]. Studies have shown that the bipolar device has the least amount of thermal spread among the various energy devices $[11,12,23]$ and provides safe sealing and cutting quality that are similar to other energy based devices [20]. Bipolar electrosurgery devices have shown to have shorter dissection time, provided better seal quality, lesser blood loss, fewer conversion rates and are more cost effective than monopolar electrosurgery [24-26]. In laparoscopic cholecystectomy (LC), a common laparoscopic procedure which involves the use of energy, bipolar modality is shown in one study to have performed better than monopolar electrosurgery [27]. In a number of other studies comparing different energy devices, the bipolar electrosurgery devices have performed better than devices using other forms of energy sources [26, 28-30]. High success rate have also been reported in surgical outcome reports using bipolar energy devices $[14,15,18]$. Hence the cost of bipolar electrosurgery devices may be justified for complex surgical cases. Monopolar technique might be preferable for simpler surgical procedures when adequate care is taken while operating in the vicinity of critical organs. For example, making incisions on the skin before inserting the 
laparoscopic instruments is a job for the monopolar tool. The risk from electrosurgery can further be reduced by limiting the thermal damage during electrosurgery. For example, Dodde et al. [31] reported a novel thermal management system to reduce the thermal spread during monopolar electrosurgery. One common safety measure is the optimization of the voltage application time. Most of the electrosurgical units come with various power settings for cutting and coagulation. The right setting should be chosen for the specific procedure. Tissue damage is further reduced by the introduction of a hydrating medium to keep the surgical area wet and moist. As long as the above mentioned precautions are taken and the common risk factors are considered, electrosurgery maybe used with confidence.

\section{Ultrasonic energy}

The use of ultrasonic energy in medicine has been reported as early as 1960, where it was used to treat Meniers's disease. It has been used in the cutting and coagulation of tissue in the late 1980s [33] where Amaral [34] popularized the technique and used it successfully in over 200 patients undergoing laparoscopic cholecystectomy.

Mechanism of Ultrasonic surgery-The basic working principle of ultrasonic surgical instruments such as ultrasonically activated scalpel (UAS) is to use the low frequency mechanical vibrations (ultrasonic energy in the range of 20-60 kHz) of the tool tips or the blades for tissue cutting and coagulation [32]. The mechanical vibrations when transferred to the tissues on contact induces protein denaturation by breaking down the hydrogen bonds in tissues due to the internal cellular friction caused by the vibrations [33]. The mechanical vibrations are produced by the piezoelectric transducers embedded in the tools which convert the applied electrical energy to mechanical vibrations which are then transferred to the active blades for cutting or coagulation. The HS operate at a frequency of $55.5 \mathrm{kHz}$ whereas devices operating at various other frequencies also exist [35].

The cutting using an Ultrasonic surgical instrument is achieved by two methods. For tissues and muscles with high protein densities, the mechanical stretching of the tissues beyond its elastic limit due to the longitudinal motion of the sharp blades between 60 to $100 \mu \mathrm{m}$ at 55.5 $\mathrm{kHz}$ is used for cutting. For tissues with low protein densities, such as liver, cavitation effect in which intercellular water is vaporized at lower temperatures due to mechanical vibrations, there by rupturing the cells is used for cutting. In general the cutting and coagulation in UAS depends on various factors such as grip pressure, the shape and area of the blades in contact with the tissues and the power settings [34].

The major advantage of using UAS is that it produces less heat compared to other energy devices (less than $80^{\circ} \mathrm{C}$ compared to $100^{\circ} \mathrm{C}$ for electrosurgery) thereby reducing the risk of thermal injury [35]. Due to lesser heat generation, charring and desiccation is also greatly reduced. Since no smoke is produced, except for the mist produced due to cavitation effect which dissipates much faster, UAS offers unobstructed view for endoscopic/ laparoscopic procedures. The UAS does not transmit active current in the tissues and thereby eliminate any risk of electric shock. The most commonly used ultrasonic energy devices are listed in Table 1.

Complications and Recurrences in ultrasonic surgery-Not many complications were reported in the use of harmonic scalpel in laparoscopy. General disadvantages of ultrasonic devices include slower coagulation compared to electrosurgery, altering of the frequency or impedance of the surgical system itself due to blade fatigue, temperature elevation, excessive applied pressure, or improper use. Ultrasonic energy causes atomization of fluid, which may create a transient mist. However, overall dissection time may be shorter with ultrasonic cavitation aspirators (UCA) or ultrasonic-activated scalpels after the initial 
learning curve [36]. It has been shown in many studies that the ultrasonic devices are not as efficient in sealing medium to large sized blood vessels [26, 37, 38]. It is also shown that UAS produces higher average temperatures [10] and is not reliable in sealing vessels larger than $3 \mathrm{~mm}$ [39]. In [40] it was shown that though there is no visible injury to naked eye during dissection experiments on a swine using a UAS, histological examination had revealed serious injuries to various structures. Complications reported in the use of ultrasonic energy in laparoscopic surgery includes injury to sigmoid colon [41], postoperative bleeding [42] and an ischemic lesion [28]. Even the overheating of tissue (the non active blade of a UAS) after a continuous activation of more than 10s resulted in histological damage to the intestinal mucosa in a porcine [43].

Indications and Contraindications of ultrasonic energy-The general conclusion of most studies advocating the use of ultrasonic energy is that the minimal thermal spread leads to minimal thermal injury. However, there are studies that contradict the statement by measuring the temperature of the tool tip instead of thermal spread in the tissue. In [44] it was shown that at higher power settings, the ultrasonic devices (Ultracision and Autosonix) created large thermal spread (up to $25.7 \mathrm{~mm}$ ) and high temperatures $\left(140^{\circ} \mathrm{C}\right.$ at $10 \mathrm{~mm}$ distance) in porcine organs. In another study, the harmonic ACE [10] is shown to have taken twice as long to cool down when compared to the other devices and the temperatures generated by the ACE were inversely proportional to the thickness of the tissue. Kinoshita et al. [48] says that the temperatures $\left(150^{\circ} \mathrm{C}\right)$ and thermal spread $(10 \mathrm{~mm})$ caused by ultrasonic device is far less than those caused by electrosurgery $\left(350^{\circ} \mathrm{C}\right.$ and $22 \mathrm{~mm}$ respectively) in the porcine blood vessel cutting and coagulation. There are various reports of successful laparoscopic procedures using ultrasonic energy devices. This includes gynecological [4548], laparoscopic cholecystectomy [49-51], laparoscopic appendectomy [52], laparoscopic myomectomy [53, 54], laparoscopic colorectal [55], laparoscopic salpingo-oophorectomy [56] and laparoscopic management of cornual heterotopic pregnancy [57]. Ultrasonic scalpel (Harmonic ACE) was also successfully used in division of pulmonary vessels in video assisted lung resection [58]. Though proven to be an effective tool in gynecological procedures, it is not a good tool for delicate reconstructive surgery for fertility due to the cavitational effect [47]. Janssen et al. [51] showed that in laparoscopic cholecystectomy, the learning curve of the surgeons using HS was very short compared to electrosurgery. The general conclusion that can be drawn from the observations is that ultrasonic energy has more advantages than disadvantages. Given the fact that more recent literature is available in the field than other energy methods and the increasing market share of ultrasonic medical devices [59], it can be said that ultrasonic energy may have an increasing role in the field of surgery.

\section{Lasers}

The first use of lasers in laparoscopic surgery was recorded in 1979 [60] and the regular use of laparoscopic laser surgery has been reported as early as 1982 [61]. In a very short span of time, lasers became very widespread in the medical field - ranging from cosmetic treatments to highly complicated surgeries such as atrial fibrillation (AF) treatment $[62,63]$. Today, lasers are relegated mostly to gynecological procedures.

Mechanism of Laser surgery-Lasers generate heat by applying a concentrated beam of light. In a laser system, electromagnetic or light waves are amplified multiple fold in an optical resonator (which contains mirrors and a gain medium) and passed out in the form of high intensity light waves. The amount of amplification in the resonator determines the amount of energy transmitted by the light waves which are then absorbed by the tissue. This energy absorbed by the tissue then manifests itself into heat which cuts and coagulates the tissue. The frequency of the laser beam determines the width of the laser beam that can be 
generated (the higher the frequency of the wave, the lower the diameter of the beam) and most commercial lasers use infra-red to ultraviolet frequencies for medical applications. The power or intensity of a laser is measured in terms of 'irradiation' defined as the ratio of power applied to the spot-size (cross sectional area) of the laser beam $\left(\mathrm{W} / \mathrm{m}^{2}\right.$ ). Though only two variables (power and spot-size) are required to calculate the value of irradiation, two other important variables need to be considered when using lasers in surgery - time of exposure and wave length (or frequency). The use of lasers to generate heat for destroying tumors is known as 'photo-thermal' therapy. The changes caused by non-thermal mechanisms while using a laser are called 'photo-chemical' processes. Usually, in photochemical processes, the amount of irradiance is so low that, instead of generating heat, it induces chemical reactions in the cells thus causing inactivity. When the amount of irradiation is too high $\left(10^{8}\right.$ to $\left.10^{9} \mathrm{~W} / \mathrm{cm}^{2}\right)$, plasma formation takes place and leads to a 'photo-plasmal' process. If the electric field is too strong, the result is a small region of plasma which is associated with dielectric breakdown, strong electric fields, shockwave formation and tissue rupture. Once the plasma forms, the tissue properties become immaterial as all the laser energy is absorbed by the plasma itself [64].

Lasers can be classified into contact or non-contact types - based on their interaction with the tissue. In non-contact laser mechanism, the tip of the laser delivery device remains at a distance from the tissue to where it is being focused. When this kind of mechanism is used in a liquid medium, an explosive vapor bubble is formed at the tip of the tool which carries energy to the tissue. This type of energy delivery is preferred in a few ablation processes [65]. The contact laser is the direct contact of the tool tip with the tissue. This causes the direct transfer of energy from the tool to the tissue. The selection of a contact or non-contact laser depends upon the sensitivity and accessibility of the tissue being operated on. The most commonly used Laser devices are listed in Table 1.

Complications and Recurrences in laser surgery-Disadvantages of laparoscopic laser surgery include cost of specialized equipment, need for advanced training in laser and laparoscopic surgery, risk of fire from flammable materials ignited by lasers and increased operative time. The increased sedation period due to the length of the operative time also leads to longer recovery time. Cellular damage around the area of laser impingement can also be expected depending upon the size of the laser tip. One of the major complications using laser as the energy source is the air embolism which can be fatal [66-77]. Another complication with laser laparoscopic cholecystectomy is the injury to the hepatic artery with pseudoaneurysm formation and hemobilia [78]. Hemorrhage has been reported in other studies as well. In a review of 2344 laser laparoscopies over an 11-year period (1982 1993), Ewen et al. [79] reported nine significant complications in which three cases of intraabdominal hemorrhage required laparotomies and one case of severe surgical emphysema during adhesiolysis with $\mathrm{CO}_{2}$ laser was also reported.

Indications and Contraindications of laser surgery-The efficiency of lasers in laparoscopy were reported as early as 1989, when Reddick et al. [80] studied 25 cases of laparoscopic cholecystectomy (in the US) and found no major complications despite having shorter recovery periods compared to open surgery. In laparoscopy, the major use of lasers is in gynaecological procedures, where it is commonly used in the treatment of infertility [81-86]. It is also a common source of energy in cosmetic and eye surgeries. Success rates of more than $90 \%$ have also been reported in review of cases that used $\mathrm{CO}_{2}$ laser along bipolar forceps in laparoscopic surgery [87, 88]. Advantages of laparoscopic laser surgery over open techniques include minimal surgical morbidity, decreased postoperative discomfort, and rapid, uncomplicated healing. Complications from laser laparoscopic surgery include air embolism, hemorrhage and surgical emphysema. Moreover a noncontact laser may do more damage than a contact laser [89]. 


\section{Argon Beam Coagulation}

Ward et al. [90] first reported the use of argon beam coagulation (ABC) in head and neck surgery in 1989. The use of ABC in MIS is first reported by Low et al. [91] in 1993. Numerous studies describing the efficiency as well as the dangers of $A B C$ have been well documented [92-94].

Mechanism of argon beam coagulation-In electrosurgery a radio frequency current is applied to tissue to cauterize and control bleeding. In $\mathrm{ABC}$, a directed beam of argon gas from the electrode tip aids in conduction of the radio frequency current to the tissue by ionization. Like laser, this is a non-contact method where the argon gas - which is a good conductor of electricity - acts as a means of transportation of the current from the tool to the tissue. $\mathrm{ABC}$ performs faster than conventional coagulation systems and provides a more uniform and shallower coagulation region which results in faster dispersion thus minimizing tissue damage. It also produces less smoke than the conventional system. Since the argon has higher density, a jet of argon gas typically move the blood away from the surface for effective coagulation and resulting in lesser eschar. The protection of the active electrode tip from exposure to oxygen also results in less charring [95]. The ABC system is usually connected together with an electrosurgical system where argon gas is released from the tip of the tool to achieve hemostasis. The most commonly used ABC devices are listed in Table 1.

Complications and Recurrences in Argon beam coagulation-A major limitation to the use of $\mathrm{ABC}$ system is the potential danger of argon gas embolism. Numerous instances of cardiac arrest were reported during the use of $\mathrm{ABC}$ due to gas embolism [93, 94, 96]. Embolism (blockage of blood vessels) occurs due to the insolubility of the argon gas in blood. The gas forms bubbles or cavities that can travel through the blood stream and cause blockages in blood vessels. Death due to argon gas embolism has also been reported [97-99]. Cases of non fatal argon gas embolism have been reported in [100-104].

Indications and Contraindications of Argon beam coagulation-Despite the risks, $\mathrm{ABC}$ continues to be used in surgery. A number of successful cases in the use of $\mathrm{ABC}$ have been reported [105-109]. Dowling et al. [110] reported that the ABC was more effective in management of spleenic trauma compared to traditional techniques(topical surgical, electrocautery, suture-ligation, digital pressure) in a study on ten adult pigs. Guidelines for the safe use of ABC during laparoscopy have been tabulated by various researchers and commercial manufacturers. Some important guidelines are, The flow rate for argon should be chosen as low as possible to reduce the risk of argon gas embolism [111], direct contact of the tool tip on the organ should be avoided and the electrode tip should be held at an oblique angle. It was mentioned in a study that even at the point of longest application, the temperature developed while using $\mathrm{ABC}$ was never higher than $100^{\circ} \mathrm{C}$ in complete coagulation [112]. There are other studies such as the one by Bobbio et al. [113] wherein argon beam technique is compared with traditional surgery in the treatment of primary spontaneous pneumothorax (PSP) using video assisted thoracic surgery (VATS) where no significant benefits of $A B C$ were found. The use of $A B C$ has resulted in numerous cases of fatal and non fatal embolisms.. So, the use of ABC must solely depend on the skill and discretion of the surgeon.

\section{Radio Frequency (RF) Energy}

Electrosurgical generators can generate EM waves in a wide range of frequencies. Radio frequency or RF which ranges from $3 \mathrm{kHz}$ to $300 \mathrm{MHz}$ is the type of electromagnetic (EM) radiation that is commonly used in electrosurgery. RF has the lowest frequency of all the EM waves and hence takes longer than other EM waves to generate heat in the tissue. It has 
been shown in a number of studies that EM in the RF range is the most effective form of radiation.

Mechanism of RF-There are two mechanisms of RF that are used in MIS. One of them is the laparoscopic electrosurgical usage of RF. The mode of operation is the same as that of electrosurgery where the current applied to the tissue through the scalpel falls is the RF range. RF in electrosurgery can be used in both monopolar and bipolar modes. Apart from laparoscopy, RF can also be used in a percutaneous setting. Percutaneous treatment involves the insertion of a needle into the organ to be operated on via a catheter inserted through the skin of the patient. RF current is then applied to the tissue through the needle. Though it is different from laparoscopy, it is also a MIS procedure where the needle tip is usually guided into the body by an ultrasound positioning system. The most commonly used RF energy devices are listed in Table 1.

Complications and Recurrences in RF-The most common usage of the RF in is radio-frequency ablation (RFA), which is also referred to as LRFA (laparoscopic radiofrequency ablation) in the laparoscopic setting. A number of studies show the application of LRFA in various procedures [17, 19, 114]. Beyer et al. [114] studied minimally invasive bipolar radiofrequency ablation of lone atrial fibrillation (AF) in 100 patients at 3 North American Institutes between 2005 and 2007 and reported postoperative complications that includes pacemaker requirement (5\%), phrenic nerve palsy $(3 \%)$, hemothorax $(3 \%)$, transient ischemic attack $(1 \%)$ and pulmonary embolism (1\%). Case of deaths and high morbidity has also been reported in laparoscopic cholecystectomy procedure in Child-Pugh Class C Cirrhotic patients using a combination of HS dissection and radiofrequency coagulation [115]. In a report submitted to the American college of physicians in 2003, it was reported that RF ablation treatment of atrial fibrillation (arrhythmias) performed using a catheter can severely narrow the pulmonary veins due to the formation of scar tissues [116]. In rare cases, acute renal failure associated with radiofrequency liver ablation has been observed [117]. Most complications of RF seem to arise when it is used in the vicinity of the heart. This is due to the interference of the electrical with the electrical activity of the heart. Persistent inappropriate sinus tachycardia has been reported as a complication after radiofrequency (RF) ablation of the fast atrioventricular (AV) nodal pathway [118]. In a study of management of hepatic malignancies using RFA of malignant liver tumors in 608 patients between 1996 and 2002 [119], hepatocellular carcinoma, followed by colorectal adenocarcinoma were reported as a major early complications and. Symptomatic pleural effusion was reported as the major postoperative complication.

Indications and Contraindications of RF-In a study on advantages of using radio frequency (RF) heating over lasers for laser cartilage reshaping (LCR), it was shown that RF method allowed more uniform heating of larger tissue samples but the lack of precise control of spatio-temporal distribution of heat limits the usage of RF use in LCR [116]. The advantages of RF energy and the necessity to reduce complications have resulted in the introduction of several new commercial devices [120, 121]. In [122], the Gyrus Plasma Trissector (GPT), a novel bipolar RF system in laparoscopic radical prostatectomies was shown to improve coagulation, reduce or eliminate sticking, seal large vessels and allow secure grasping and dissecting of tissue. Ligasure, a radio-frequency-energy-driven bipolar fusion device is used in many laparoscopic procedures [123-127]. For the minimally invasive treatment of localized renal tumor, RFA along with cryoablation is shown to be the most used and potentially promising therapies [128]. For the treatment of renal cell carcinoma, it was shown in [129] that RFA assisted laparoscopic partial nephrectomy was effective in providing hemostasis and in short term cancer control and also shown in [130] 
that RFA treatment for small renal cell carcinoma found have significantly improved the quality of life in most of the patients. In [131], it is also reported the reduction of intraoperative bleeding and blood transfusion using RF assisted laparoscopic liver resection. However, Hompes et al. [132] states that the laparoscopic liver resection itself is a procedure with minimal blood loss and that radiofrequency assistance has no additional advantage. In a comparative study between saline infused RFA and dry RFA [133], it was shown that wet RFA caused larger lesion sizes in 10 porcine kidneys and one cycle of wet RFA was sufficient to cause irreversible cell death compared to two cycles required using dry RFA. Although, percutaneous RFA in liver treatments is less invasive and is considered the first choice, RFA with laparoscopic guidance is highly recommended for patients with a relative contraindication for percutaneous RFA, such as lesions adjacent to the gastrointestinal tract, gallbladder, bile duct and heart [134]. Similarly, LRFA was also highly recommended for the treatment of hepatocellular carcinoma [135]. In general, the most usage of RFA either laparoscopically or percutaneously is observed in the liver and renal tumor ablation. However, a variety of studies featuring RFA in various surgeries also exists. RFA is reported in the treatment of lower extremity varicosities (a minimally invasive cosmetic procedure) where it fared better than stripping and foam sclerotherapy, although not as effective as laser therapy [136]. A study of bipolar RF in the treatment of plantar fasciosis [137] in patients who couldn't be treated with conservative methods showed an improvement in all 10 patients within a time span of 6 months to 1 year without any postoperative complications.

\section{Comparison study}

In a comparative study, it is important to understand the use of energy devices in the context of individual procedures. In this paper, we consider the laparoscopic cholecystectomy (LC) procedure an example (Table 2). In LC the common energy sources used are laser, electrosurgery and ultrasonic energy. Since many of the case studies don't explicitly state injuries occurred while using the energy device, for LC, parameters such as mean operating time, mean hospital stay, mean recovery time along with complications such as bile duct injury (BDI), bile leak, conversion rate to open surgery and any reported death were collected for each study and represented in Table 2. From the data, HC and Ultrasonically Activated Scalpel (UAS) performed better than clip and electrosurgery methods based on operating time and bile duct injuries. Huscher et al. [138] sates that the main advantage of UAS is the low-risk dissection in the proximity of biliary structures. More over with UAS both cystic duct and vessels can be separated without the need for ligature. The relative bloodless field of view when using UAS also helps in discriminating anatomical structures. Redwan et al. [139] states that when comparing HS and clip and electrosurgery for LC, HS performed better with lesser operating time and the absence of major or minor bile leaks. No clear conclusion can be made regarding laser since the operating time and injuries when compared to clip and electrosurgery varied among the different studies and no direct comparison study exists between laser and ultrasonically activated devices. Between monopolar and bipolar electrosurgery, though both had comparable operating time, monopolar electrosurgery had more complications.

\section{Discussion}

A comparative study of the literature shows that the preferred source of energy in laparoscopic surgery in the early 1990s was the monopolar electrosurgery, while bipolar and laser was used much less frequently. However, in recent times, even with the advent of new tools in electrosurgery, the preference is gradually shifting towards ultrasonic energy due to its many advantages in laparoscopy. While laparoscopic laser cholecystectomy, once a popular procedure, is rarely performed and harmonic scalpel (HS) has been used more often 
in recent times. Fiber optic cables have made lasers more readily available in laparoscopy. The use of lasers is most dominant in gynecological treatments like endometriosis. Argon beam coagulation $(\mathrm{ABC})$ is a very effective technique to attain hemostasis, and despite the large number of deaths and intra-operative complications, it still remains in use.

In spite of significant developments, the search for an ideal energy device that will result in perfect hemostasis with minimum damage to surrounding tissue in the most efficient manner posing the minimum threat to the patient in terms of short and long term complications remains elusive. Each energy method has advantages and disadvantages and a thorough knowledge of each devices is essential in deciding which energy source for be used for a specific procedure. Relative advantages and disadvantages of existing energy methods are presented in Table 3.

In a 2004 paper, Harrell et al. [140] mention that in a survey of 500 surgeons in 1993, 18\% (of over 500 respondents) reported to have caused electrosurgical injury during laparoscopy and 54\% reported to have known of another surgeon who has caused similar injury. Deaths were more common during early in era of laparoscopy. A brief search of the literature shows numerous instances of deaths in the 1980s using various energy sources. The number of deaths and even the complications in laparoscopy, have greatly reduced in recent times. For example, complications in laparoscopic cholecystectomy, which were reported to be around $2-4 \%$ in 1994 [141], came down to about $0.4 \%$ by 2005 [142]. Table 4 shows the various deaths reported in laparoscopy using energy sources.

In general, most of the studies suggest that the effect of any laparoscopic procedure depends on the skill and familiarity of the surgeon with the surgical tools. An interesting observation while reviewing studies performed to test various instruments or methods is that some of the results seem contradicting. Devices which have been rated high by some studies have been rated low in others. Surgical skill and familiarity with the particular device may certainly be a possible contributor to this apparent paradox. Further, the devices which are shown to work well in the laboratory may not work the same way in an actual laparoscopic procedure. Hence, there is a need for developing uniform training regimens across surgical specialties under clinical conditions. Particularly, the fundamental understanding of how each of the energy devices work and their effect on the tissues is very important. For example, in electrosurgery, the understanding of different power settings and its effects on tissues is very important. More over the knowledge of safety issues with each of the devices should also be known so that appropriate precautions could be used to minimize injury. Solid communication and team coordination in high fire risk setting must be introduced into practice. Examples are the high temperature and low cooling rate of ultrasonically activated devices even after switched off, risk of air embolism in laser from high flow rate gas cooling and venous gas embolism while using $\mathrm{ABC}$. A standardized curriculum or manual with working principles of various energy devices and their safety issues as envisioned by the FUSE program would be a valuable tool in increasing patient safety in surgical procedures using energy devices.

\section{Conclusions}

Each of the energy devices reviewed in this work had its own advantages and disadvantages. When considering thermal damage, monopolar electrosurgery results in the greatest amount of thermal damage to adjacent tissue while ultrasonic energy results in the least. In terms of their performance, ultrasonic devices provide the highest seal strength in smaller vessels, while electrosurgery is more efficient for larger vessels. Argon beam coagulation results in the most effective hemostasis on irregular surfaces, however, it also leads to gas embolism. In electrosurgery, RF is the most common form of electromagnetic radiation used followed 
by microwave radiation. Lasers are very expensive and are mostly limited to gynecological treatments in laparoscopy today, though at one time, they were widely used in many laparoscopic procedures such as cholecystectomy. In blood vessel sealing, the effectiveness of an energy device is dependent on the size of the blood vessel. Though there is no clear winner in terms of operating time, in the series of study that were reviewed in this work, the harmonic scalpel is shown to have reduced overall time compared to other energy sources in MIS. In terms of death from complications, lasers and ABC have more reported cases than the other methods and surgeons should be familiar in their use. Electrosurgery is still very popular in MIS due to its familiarity with surgeons and the development of various enhanced safety features to minimize injuries.

\section{Acknowledgments}

Funding: NIBIB/NIH grants \# R01EB010037, \# R01 EB009362, \# R01 EB005807 and \# R01 EB014305

\section{References}

1. Wu M-P, Ou C-S, Chen S-L, Yen EYT, Rowbotham R. Complications and recommended practices for electrosurgery in laparoscopy. The American Journal of Surgery. 2000; 179(1):67-73.

2. Feldman L, Fuchshuber P, Jones D, Mischna J, Schwaitzberg S, Force tFT. Surgeons don't know what they don't know about the safe use of energy in surgery. Surgical Endoscopy. 2012; 26(10): 2735-9.10.1007/s00464-012-2263-y [PubMed: 22538677]

3. Cushing H, Bovie WT. Electrosurgery as an aid to the removal of intracranial tumors. Surgery Gynecology And Obstetrics. 1928; 47:751-84.

4. Albert, M.; Ellis, CN.; Fleshman, J.; Margolin, D.; Ng, PC.; Podnos, YD. The Effective Use of the ENSEAL System in Colorectal Surgery. 2010.

5. Lee J. Update on Electrosurgery. Outpatient Surgery. 2002; 3(2)

6. Govekar H, Robinson T, Varosy P, Girard G, Montero P, Dunn C, et al. Effect of monopolar radiofrequency energy on pacemaker function. Surgical Endoscopy. 2012; 26(10):2784-8.10.1007/ s00464-012-2279-3 [PubMed: 22538687]

7. Montero P, Robinson T, Weaver J, Stiegmann G. Insulation failure in laparoscopic instruments. Surgical Endoscopy. 2009; 24(2):462-5.10.1007/s00464-009-0601-5 [PubMed: 19572175]

8. Vancaillie TG. Active electrode monitoring. Surgical Endoscopy. 1998; 12(8):1009-12.10.1007/ s004649900769 [PubMed: 9685531]

9. Valleylab. Clinical Information Hotline News. 1999. Basics of Bipolar Electrosurgery.

10. Kim F, Chammas M, Gewehr E, Morihisa M, Caldas F, Hayacibara E, et al. Temperature safety profile of laparoscopic devices: Harmonic ACE (ACE), Ligasure V (LV), and plasma trisector (PT). Surgical Endoscopy. 2008; 22(6):1464-9. [PubMed: 18027042]

11. Box GN, Lee HJ, Abraham JB, Deane LA, Elchico ER, Abdelshehid CA, et al. Comparative Study of In Vivo Lymphatic Sealing Capability of the Porcine Thoracic Duct Using Laparoscopic Dissection Devices. The Journal of Urology. 2009; 181(1):387-91. [PubMed: 19010491]

12. Sutton PA, Awad S, Perkins AC, Lobo DN. Comparison of lateral thermal spread using monopolar and bipolar diathermy, the Harmonic Scalpel ${ }^{\mathrm{TM}}$ and the Ligasure ${ }^{\mathrm{TM}}$. British Journal of Surgery. 2010; 97(3):428-33. [PubMed: 20101674]

13. Tulikangas PK, Smith T, Falcone T, Boparai N, Walters MD. Gross and histologic characteristics of laparoscopic injuries with four different energy sources. Fertility and Sterility. 2001; 75(4):80610. [PubMed: 11287039]

14. Gol M, Kizilyar A, Eminoglu M. Laparoscopic hysterectomy with retroperitoneal uterine artery sealing using LigaSure: Gazi hospital experience. Arch Gynecol Obstet. 2007; 276(4):311-4. [PubMed: 17372751]

15. Kriplani A, Garg P, Sharma M, Lal S, Agarwal N. A review of total laparoscopic hysterectomy using LigaSure uterine artery-sealing device: AIIMS experience. J Laparoendosc Adv Surg Tech A. 2008; 18(6):825-9. [PubMed: 18999973]

Surg Endosc. Author manuscript; available in PMC 2014 September 01. 
16. Polychronidis A, Tsaroucha AK, Karayiannakis AJ, Perente S, Efstathiou E, Simopoulos C. Delayed Perforation of the Large Bowel due to Thermal Injury during Laparoscopic Cholecystectomy. The Journal of International Medical Research. 2005; 33:360-3. [PubMed: 15938598]

17. Siperstein A, Garland A, Engle K, Rogers S, Berber E, Foroutani A, et al. Local recurrence after laparoscopic radiofrequency thermal ablation of hepatic tumors. Ann Surg Oncol. 2000; 7(2):10613. [PubMed: 10761788]

18. Darai E, Ackerman G, Bazot M, Rouzier R, Dubernard G. Laparoscopic segmental colorectal resection for endometriosis: limits and complications. Surgical Endoscopy. 2007; 21(9):1572-7. [PubMed: 17342560]

19. Berber E, Siperstein A. Local recurrence after laparoscopic radiofrequency ablation of liver tumors: an analysis of 1032 tumors. Ann Surg Oncol. 2008; 15(10):2757-64. [PubMed: 18618182]

20. Peterson HB, Ory HW, Greenspan JR Jr, TCW. Deaths associated with laparoscopic sterilization by unipolar electrocoagulating devices, 1978 and 1979. Am J Obstet Gynecol. 1981; 139(2):1413. [PubMed: 6450536]

21. Willson PD, McAnena OJ, Peters EE. A fatal complication of diathermy in laparoscopic surgery. Minimally Invasive Therapy \& Allied Technologies. 1994; 3(1):1920.10.3109/13645709409152989

22. Agarwal B, Gupta M, Agarwal S, Mahajan K. Anatomical footprint for safe laparoscopic cholecystectomy without using any energy source: a modified technique. Surgical Endoscopy. 2007; 21(12):2154-8. [PubMed: 17479331]

23. Matthews B, Nalysnyk L, Estok R, Fahrbach K, Banel D, Linz H, et al. Ultrasonic and Nonultrasonic Instrumentation: A Systematic Review and Meta-analysis. Arch Surg. 2008; 143(6): 592-600.10.1001/archsurg.143.6.592 [PubMed: 18559754]

24. Hubner M, Demartines N, Muller S, Dindo D, Clavien PA, Hahnloser D. Prospective randomized study of monopolar scissors, bipolar vessel sealer and ultrasonic shears in laparoscopic colorectal surgery. British Journal of Surgery. 2008; 95(9):1098-104. [PubMed: 18690630]

25. Targarona EM, Balague C, Marin J, Neto RB, Martinez C, Garriga J, et al. Energy Sources for Laparoscopic Colectomy: A Prospective Randomized Comparison of Conventional Electrosurgery, Bipolar Computer-Controlled Electrosurgery and Ultrasonic Dissection. Operative Outcome and Costs Analysis. Surgical Innovation. 2005; 12(4):33944.10.1177/155335060501200409 [PubMed: 16424955]

26. Hruby GW, Marruffo FC, Durak E, Collins SM, Pierorazio P, Humphrey PA, et al. Evaluation of Surgical Energy Devices for Vessel Sealing and Peripheral Energy Spread in a Porcine Model. The Journal of Urology. 2007; 178(6):2689-93. [PubMed: 17945280]

27. Edelman DS, Unger SW. Bipolar Versus Monopolar Cautery Scissors for Laparoscopic Cholecystectomy: A Randomized, Prospective Study. Surgical Laparoscopy Endoscopy \& Percutaneous Techniques. 1995; 5(6):459-62.

28. Campagnacci R, de Sanctis A, Baldarelli M, Rimini M, Lezoche G, Guerrieri M. Electrothermal bipolar vessel sealing device vs. ultrasonic coagulating shears in laparoscopic colectomies: a comparative study. Surgical Endoscopy. 2007; 21(9):1526-31. [PubMed: 17287913]

29. Demirturk F, Aytan H, Caliskan AC. Comparison of the use of electrothermal bipolar vessel sealer with harmonic scalpel in total laparoscopic hysterectomy. The Journal of Obstetrics and Gynaecology Research. 2007; 33:341-5. [PubMed: 17578364]

30. Lamberton GR, Hsi RS, Jin DH, Lindler TU, Jellison FC, Baldwin DD. Prospective comparison of four laparoscopic vessel ligation devices. JOURNAL OF ENDOUROLOGY. 2008; 22(10):230712. [PubMed: 18831673]

31. Dodde R, Gee JS, Geiger JD, Shih AJ. Monopolar Electrosurgical Thermal Management System to Reduce Lateral Thermal Damage During Surgery. Journal of Medical Devices. 2010; 4(2): 027505-1.

32. O’Daly BJ, Morris E, Gavin GP, O’Byrne JM, McGuinness GB. High-power low-frequency ultrasound: A review of tissue dissection and ablation in medicine and surgery. Journal of Materials Processing Technology. 2008; 200(1-3):38-58. 
33. Smith R, Pasic R. The role of vessel sealing technologies in laparoscopic surgery. Surg Technol Int. 2008; 17:208- 12. [PubMed: 18802904]

34. Lee SJ, Park KH. Ultrasonic energy in endoscopic surgery. Yonsei Med J. 1999; 40(6):545-9. [PubMed: 10661030]

35. Liano, C. The Washington Times Web site. 2004. Curbing laparoscopy burns.

36. Ghosh P. Ultrasonic Devices in Cardiac Surgery. Asian Cardiovasc Thorac Ann. 1999; 7(4):333-8.

37. Clements R, Palepu R. In vivo comparison of the coagulation capability of SonoSurg and Harmonic Ace on $4 \mathrm{~mm}$ and $5 \mathrm{~mm}$ arteries. Surgical Endoscopy. 2007; 21(12):2203-6. [PubMed: 17479325]

38. Harold KL, Pollinger H, Matthews BD, Kercher KW, Sing RF, Heniford BT. Comparison of ultrasonic energy, bipolar thermal energy, and vascular clips for the hemostasis of small-, medium-, and large-sized arteries. Surgical Endoscopy. 2003; 17(8):1228-30. [PubMed: 12799888]

39. Wolfe BM, Gardiner BN, Leary BF, Frey CF. Endoscopic Cholecystectomy: An Analysis of Complications. Arch Surg. 1991; 126(10):1192-8.10.1001/archsurg.1991.01410340030005 [PubMed: 1834039]

40. Kadesky KM, Schopf B, Magee JF, Blair GK. Proximity injury by the ultrasonically activated scalpel during dissection. Journal of Pediatric Surgery. 1997; 32(6):878-9. [PubMed: 9200091]

41. Awwad JT, Isaacson K. The harmonic scalpel: an intraoperative complication. Obstet Gynecol. 1996; 88(4):718-20. [PubMed: 8841266]

42. McNally ML, Erturk E, Oleyourryk G, Schoeniger L. Laparoscopic Cyst Decortication Using the Harmonic Scalpel for Symptomatic Autosomal Dominant Polycystic Kidney Disease. Journal Of Endourology. 2001; 15(6):597-9. [PubMed: 11552783]

43. Kim JS, Hattori R, Yamamoto T, Yoshino Y, Gotoh M. How can we safely use ultrasonic laparoscopic coagulating shears? International Journal of Urology. 2010; 17:377-81. [PubMed: 20409232]

44. Emam TA, Cuschieri A. How Safe is High-Power Ultrasonic Dissection? Annals of Surgery. 2003; 237(2):186-91. [PubMed: 12560776]

45. Schwartz RO. Total Laparoscopic Total Hysterectomy with the Harmonic Scalpel. Journal of Gynecologic Surgery. 1994; 10(1):33-4.

46. Giannopoulos T, Chipchase J, Tailor A, Butler-Manuel S. The use of harmonic shears (Ultracision) for laparoscopic lymphadenectomies in women with gynaecological malignancies. Gynecological Surgery. 2005; 2(2):97-100.

47. Jansen FW, Trimbos-Kemper T, Baptist Trimbos J. Ultrasonic scalpel in laparoscopic gynaecological surgery: an observational study in 354 cases. Gynaecological Endoscopy. 2002; 11(1):47-51.

48. Lin J, Zhang X, Xu K. Application of ultrasonic scalpel in gynecologic operative laparoscopy. Chinese Medical Journal. 2001; 114(12):1283-5. [PubMed: 11793854]

49. Amarin NS. Harmonic Scalpel and Clipless Cholecystectomy. World Journal of Laparoscopic Surgery. 2008; 1(2):6-8.

50. Gelmini R, Franzoni C, Zona S, Andreotti A, Saviano M. Laparoscopic cholecystectomy with Harmonic scalpel. JSLS, Journal of the Society of Laparoendoscopic Surgeons. 2010; 14(1):14-9.

51. Janssen IMC, Swank DJ, Boonstra O, Knipscheer BC, Klinkenbijl JHG, van Goor H. Randomized clinical trial of ultrasonic versus electrocautery dissection of the gallbladder in laparoscopic cholecystectomy. British Journal of Surgery. 2003; 90(7):799-803. [PubMed: 12854103]

52. Elattar OM, Naga AAE, Maged H. Laparoscopic appendectomy by ultrasonically activated scalpel: a prospective study. Egyptian Journal of Surgery. 2005; 24(3):164-7.

53. Lin PC, Thyer A, Soules MR. Intraoperative ultrasound during a laparoscopic myomectomy. Fertility and Sterility. 2004; 81(6):1671-4. [PubMed: 15193493]

54. Stringer NH. Laparoscopic Myomectomy with the Harmonic Scalpel: A Review of 25 Cases. Journal of Gynecologic Surgery. 1994; 10(4):241-5. 
55. Msika S, Deroide G, Kianmanesh R, Iannelli A, Hay J-M, Fingerhut A, et al. Harmonic scalpel in laparoscopic colorectal surgery. Diseases of the Colon \& Rectum. 2001; 44(3):432-6. [PubMed: 11289292]

56. Vetere PF, Apostolis C. Ureteral Injury Due to a Harmonic Scalpel During Laparoscopic Salpingooophorectomy. JSLS, Journal of the Society of Laparoendoscopic Surgeons. 2010; 14(1):115-9.

57. Chachan S, Waters N, Kent A. Laparoscopic management of cornual heterotopic pregnancy with the use of Harmonic ACE®—a case report. Gynecological Surgery. 2009:1-4.

58. Tanaka T, Ueda K, Hayashi M, Hamano K. Clinical application of an ultrasonic scalpel to divide pulmonary vessels based on laboratory evidence. Interact CardioVasc Thorac Surg. 2009; 8(6): 615-8.10.1510/icvts.2008.200584 [PubMed: 19299424]

59. Driscoll, P. Energy-Based Devices in General Surgery. MedMarket Diligence, LLC; 2006.

60. Bruhat, M.; Mage, C.; Manhes, M., editors. Use of carbon dioxide laser via laparoscopy; Laser Surgery III Proceedings of the Third Congress for the International Society for Laser Surgery; Kaplan: 1979. Published

61. Sutton C. Initial experience with carbon dioxide laser laparoscopy. Lasers in Medical Science. 1986; 1(1):25-31.

62. Hamman, BL.; Theologes, TT., editors. Baylor University Medical Center Proceedings. 2009. Surgical treatment of atrial fibrillation with diode-pumped laser. Published

63. Williams MR, Casher JM, Russo MJ, Hong KN, Argenziano M, Oz MC. Laser Energy Source in Surgical Atrial Fibrillation Ablation: Preclinical Experience. The Annals of Thoracic Surgery. 2006; 82(6):2260-4. [PubMed: 17126144]

64. Welch AJ, Torres JH, Cheong W-F. Laser Physics and Laser-Tissue Interaction. Texas Heart Institute Joumal. 1989; 16(3):141-9.

65. Gerber GS. Lasers in the treatment of benign prostatic hyperplasia. Urology. 1995; 45(2):193-9. [PubMed: 7531898]

66. Baggish MS, Daniell JF. Death caused by air embolism associated with neodymium:yttriumaluminum-garnet laser surgery and artificial sapphire tips. American journal of obstetrics and gynecology. 1989; 161(4):877-8. [PubMed: 2486191]

67. Challener RC, Kaufman B. Fatal venous air embolism following sequential unsheathed (bare) and sheathed quartz fiber Nd:YAG laser endometrial ablation. Anesthesiology. 1990; 73(3):548-51. [PubMed: 2393141]

68. Greville AC, Clements EAF, Erwin DC, McMillan DL, Wellwood JM. Pulmonary air embolism during laparoscopic laser cholecystectomy. Anaesthesia. 1991; 46:113-4. [PubMed: 1831331]

69. Lang NP, Wait GM, Read RR. Cardio-cerebrovascular complications from Nd:YAG laser treatment of lung cancer. American journal of surgery. 1991; 162(6):629-32. [PubMed: 1670239]

70. Messiant F, Marquette C, Neviere R, Ramon P, Duverger D, Mathieu D. Systemic air embolism after laser resection of a tracheal tumor. Intensive Care Medicine. 1995; 21(2):192-3. [PubMed: 7775705]

71. Peachey T, Eason J, Moxham J, Jarvis D, Driver M. Systemic air embolism during laser bronchoscopy. Anaesthesia. 1988; 43(10):872-5. [PubMed: 3202299]

72. Ross DJ, Mohsenifar Z, Potkin RT, Roston WL, Shapiro SM, Alexander JM. Pathogenesis of cerebral air embolism during neodymium-YAG laser photoresection. Chest. 1988; 94(3):660-2. [PubMed: 3409759]

73. Yuan HB, Poon KS, Chan KH, Lee TY, Lin CY. Fatal gas embolism as a complication of NdYAG laser surgery during treatment of bilateral choanal stenosis. International Journal of Pediatric Otorhinolaryngology. 1993; 27(2):193-9. [PubMed: 8258488]

74. Baggish MS, Daniell JF. Catastrophic injury secondary to the use of coaxial gas-cooled fibers and artificial sapphire tips for intrauterine surgery: A report of five cases. Lasers in Surgery and Medicine. 1989; 9(6):581-4. [PubMed: 2601551]

75. Kelly M, Mathews HML, Weir P. Carbon dioxide embolism during laser endometrial ablation. Anaesthesia. 1997; 52(1):65-7. [PubMed: 9014548]

76. Schröder TM, Puolakkainen PA, Hahl J, Rämö OJ. Fatal air embolism as a complication of laserinduced hyperthermia. Lasers in Surgery and Medicine. 1989; 9(2):183-5. [PubMed: 2716463] 
77. Tellides G, Ugurlu BS, Kim RW, Hammond GL. Pathogenesis of Systemic Air Embolism During Bronchoscopic Nd:YAG Laser Operations. Ann Thorac Surg. 1998; 65(4):930-4. [PubMed: 9564904]

78. Genyk YS, Keller FS, Halpern NB. Hepatic artery pseudoaneurysm and hemobilia following laser laparoscopic cholecystectomy. Surgical Endoscopy. 1994; 8(3):201-4. [PubMed: 8191359]

79. Ewen S, Sutton CJG. Complications of laser laparoscopy: Eleven years experience. Minimally Invasive Therapy \& Allied Technologies. 1995; 4(1):27-9.10.3109/13645709509152749

80. Reddick EJ, Olsen DO. Laparoscopic laser cholecystectomy. Surgical Endoscopy. 1989; 3(3):1313. [PubMed: 2530643]

81. Goldenberg M, Bider d, et al. Pregnancy: Laparosocopic laser surgery of primary ovarian pregnancy. Human Reproduction. 1994; 9(7):1337-8. [PubMed: 7962444]

82. Langebrekke A, Kirschner R, Skår OJ, Sørnes T, Urnes A. Treatment of tubal pregnancy by laparoscopic laser surgery. Acta Obstetricia et Gynecologica Scandinavica. 1991; 70(4-5):3314.10.3109/00016349109007882 [PubMed: 1836086]

83. Langebrekke A, Sarnes T, Urnes A. Fertility outcome after treatment of tubal pregnancy by laparoscopic laser surgery. Acta Obstetricia et Gynecologica Scandinavica. 1993; 72(7):5479.10.3109/00016349309058161 [PubMed: 8213102]

84. Sutton CJG, Ewen SP, Jacobs SA, Whitelaw NL. Laser laparoscopic surgery in the treatment of ovarian endometriomas. The Journal of the American Association of Gynecologic Laparoscopists. 1997; 4(3):319-23. [PubMed: 9154780]

85. Weather LJ. Carbon Dioxide Laser Laparoscopy in Treatment of Infertility and Disorders Associated with Pelvic Pain. J Natl Med Assoc. 1988; 80(2):185-7. [PubMed: 2977189]

86. Shumalinsky D, Lobik L, Cytron S, Halpern M, Vasilyev T, Ravid A, et al. Laparoscopic Laser Soldering for Repair of Ureteropelvic Junction Obstruction in the Porcine Model. Journal of Endourology. 2004; 18(2):177-81.10.1089/089277904322959833 [PubMed: 15072627]

87. Karaman Y, Bingol B, Günenç Z. Prevention of complications in laparoscopic hysterectomy: Experience with 1120 cases performed by a single surgeon. Journal of Minimally Invasive Gynecology. 2006; 14(1):78-84. [PubMed: 17218235]

88. Liu CY. Laparoscopic hysterectomy. A review of 72 cases. J Reprod Med. 1992; 37(4):351-4. [PubMed: 1534374]

89. Wishnow KI, Johnson DE, Cromeens DM, Ro JY. Laser photoirradiation of the canine ureteral orifice: Comparison between contact and noncontact techniques. Lasers in Surgery and Medicine. 1989; 9(5):485-9. [PubMed: 2811571]

90. Ward PH, Castro DJ, Ward S. A Significant New Contribution to Radical Head and Neck Surgery: The Argon Beam Coagulator as an Effective Means of Limiting Blood Loss. Arch Otolaryngol Head Neck Surg. 1989; 115(8):921-3.10.1001/archotol.1989.01860320031013 [PubMed: 2751850]

91. Low RK, Moran ME. Laparoscopic argon beam coagulation: Implications for reconstructive urology. Minimally Invasive Therapy \& Allied Technologies. 1993; 2(2):758.10.3109/13645709309152671

92. Bowling DM. Argon beam coagulation for post-tonsillectomy hemostasis. Otolaryngology - Head and Neck Surgery. 2002; 126(3):316-20. [PubMed: 11956541]

93. Cornejo A, Liao L, Kenneth W. Argon gas embolism with the use of argon beam coagulation during open hepatic resection. The Internet Journal of Surgery. 2010; 22(2)

94. Ikegami T, Shimada M, Imura S, Nakamura T, Kawahito S, Morine Y, et al. Argon gas embolism in the application of laparoscopic microwave coagulation therapy. Journal of Hepato-BiliaryPancreatic Surgery. 2009; 16(3):394-8. [PubMed: 19209380]

95. Bateman SN, Noorily AD, McGuff HS. Sharp Dissection, Electrosurgery, and Argon-Enhanced Electrosurgery in Porcine Skin Flaps. Otolaryngology -- Head and Neck Surgery. 1996; 114(3): 435-42. [PubMed: 8649878]

96. Kono M, Yahagi N, Kitahara M, Fujiwara Y, Sha M, Ohmura A. Cardiac arrest associated with use of an argon beam coagulator during laparoscopic cholecystectomy. European Journal of Cardiothoracic Surgery. 2001; 87(4):644-6.10.1093/bja/87.4.644 
97. Sezeur A, Partensky C, Chipponi J, Duron J-J. Death During Laparoscopy: Can 1 Gas Push Out Another? Danger of Argon Electrocoagulation. Surg Laparosc Endosc Percutan Tech. 2008; 18(4): 395-7. [PubMed: 18716541]

98. Fatal gas embolism caused by overpressurization during laparoscopic use of argon enhanced coagulation. Health Devices. 1994; 23(6):257- 9. [PubMed: 7852075]

99. Ousmane ML, Fleyfel M, Vallet B. Venous gas embolism during liver surgery with argonenhanced coagulation. European Journal of Anaesthesiology. 2002; 19(3):225. [PubMed: 12071243]

100. Kizer N, Zighelboim I, Rader JS. Cardiac Arrest During Laparotomy With Argon Beam Coagulation of Metastatic Ovarian Cancer. International Journal of Gynecological Cancer. 2009; 19(2):237-8.10.1111/IGC.0b013e31819c54db [PubMed: 19395999]

101. Mastragelopulos N, Sarkar MR, Kaissling G, Bähr R, Daub D. Argon gas embolism in laparoscopic cholecystectomy with the Argon Beam One coagulator. Chirurg. 1992; 63(12): 1053-4. [PubMed: 1490413]

102. Reddy C, Majid A, Michaud G, Feller-Kopman D, Eberhardt R, Herth F, et al. Gas Embolism Following Bronchoscopic Argon Plasma Coagulation. Chest. 2008; 134(5):1066-9.10.1378/ chest.08-0474 [PubMed: 18988782]

103. Stojeba N, Mahoudeau G, Segura P, Meyer C, Steib A. Possible venous argon gas embolism complicating argon gas enhanced coagulation during liver surgery. Acta Anaesthesiologica Scandinavica. 1999; 43(8):866-7. [PubMed: 10492418]

104. Veyckemans F, Michel I. Venous Gas Embolism from an Argon Coagulator. Anesthesiology. 1996; 85(2):443-4. [PubMed: 8712472]

105. Kwon AH, Inui H, Kamiyama Y. Successful laparoscopic haemostasis using an argon beam coagulator for blunt traumatic splenic injury. Eur J Surg. 2001; 167(4):316-8. [PubMed: 11354328]

106. Lurie S, Gur D, Glezerman M. Argon beam coagulation during caesarean section. BJOG: An International Journal of Obstetrics \& Gynaecology. 2002; 109(12):1415. [PubMed: 12504984]

107. Lucioni A, Orvieto MA, Zorn KC, Lotan T, Gong EM, Steinberg GD, et al. Efficacy of the argon beam coagulator alone in obtaining hemostasis after laparoscopic porcine heminephrectomy: a pilot study. Can J Urol. 2008; 15(3):4091-6. [PubMed: 18570715]

108. Meyer-Junghaenel L, Giest H, Waldschmidt. Laparoscopic Argon-Beam Coagulation in Relapsing Congenital Dysontogenic Splenic Cysts. Pediatric Endosurgery \& Innovative Techniques. 2001; 5(3):315-8.10.1089/10926410152634466

109. Okada T, Sasaki F, Kurauchi N, Kubota M, Itoh T, Honda S, et al. Laparoscopic liver biopsy using cup-shaped punch biopsy forceps and argon beam coagulator in children. Pediatric Surgery International. 2007; 23(10):947-51. [PubMed: 17657501]

110. Dowling RD, Ochoa J, Yousem SA, Peitzman A, Udekwu AO. Argon Beam Coagulation is Superior to Conventional Techniques in Repair of Experimental Splenic Injury. The Journal of Trauma. 1991; 31(5):717-21. [PubMed: 2030520]

111. Palmer M, Miller CW III, CWVW, Orton EC. Venous Gas Embolism Associated with ArgonEnhanced Coagulation of the Liver. Journal of Investigative Surgery. 1993; 6(5):391-9. [PubMed: 8292567]

112. Falbo B, Vene M, Visini R, Grottola T, Di Paolo S, Picardi N. Experimental study of the effect of the Argon Beam Coagulator on organic tissues from the viewpoint of surgical utilization. Annali Italiani Di Chirurgia. 2004; 75(1):59-62. [PubMed: 15283389]

113. Bobbio A, Ampollini L, Internullo E, Caporale D, Cattelani L, Bettati S, et al. Thoracoscopic parietal pleural argon beam coagulation versus pleural abrasion in the treatment of primary spontaneous pneumothorax. European Journal of Cardio-thoracic Surgery. 2006; 29(1):68.10.1016/j.ejcts.2005.10.034 [PubMed: 16337391]

114. Beyer, E.; Lee, R.; Lam, B-K. Point: Minimally invasive bipolar radiofrequency ablation of lone atrial fibrillation: Early multicenter results. 2009. p. 521-6.

115. Currò G, Iapichino G, Melita G, Lorenzini C, Cucinotta E. Laparoscopic Cholecystectomy in Child-Pugh Class C Cirrhotic Patients JSLS. Journal of the Society of Laparoendoscopic Surgeons. 2005; 9(3):311-5. [PubMed: 16121878] 
116. Saad EB, Marrouche NF, Saad CP, Ha E, Bash D, White RD, et al. Radiofrequency Treatment of Abnormal Heart Rhythm Can Damage the Vessels That Return Blood from the Lungs to the Heart. Annals of Internal Medicine. 2003

117. Keltner JR, Donegan E, Hynson JM, Shapiro WA. Acute Renal Failure After Radiofrequency Liver Ablation of Metastatic Carcinoid Tumor. Anesthesia \& Analgesia. 2001; 93:587-9. [PubMed: 11524322]

118. Kocovic DZ, Harada T, Shea JB, Soroff D, Friedman PL. Alterations of heart rate and of heart rate variability after radiofrequency catheter ablation of supraventricular tachycardia. Delineation of parasympathetic pathways in the human heart. Circulation. 1993; 88(4):1671-81. [PubMed: 8403312]

119. Curley SA, Marra P, Beaty K, et al. Early and Late Complications After Radiofrequency Ablation of Malignant Liver Tumors in 608 Patients. Ann Surg. 2004; 239(4):450-8. [PubMed: 15024305]

120. Koffron AJ, Stein JA. Laparoscopic liver surgery: parenchymal transection using saline-enhanced electrosurgery. HPB (Oxford). 2008; 10(4):225-8. [PubMed: 18773098]

121. Yim APC, Rendina EA, Hazelrigg SR, Chow LTC, Lee T-W, Wan S, et al. A new technological approach to nonanatomical pulmonary resection: saline enhanced thermal sealing. The Annals of Thoracic Surgery. 2002; 74(5):1671-6. [PubMed: 12440628]

122. Gozen AS, Teber D, Rassweiler JJ. Principles and initial experience of a new device for dissection and hemostasis. Minim Invasive Ther Allied Technol. 2007; 16(1):5865.10.1080/13645700701191537 [PubMed: 17365678]

123. Zarebczan B, Mohanty D, Chen H. A Comparison of the LigaSure and Harmonic Scalpel in Thyroid Surgery: A Single Institution Review. Annals of Surgical Oncology. 2010:1-5. [PubMed: 20013314]

124. Munver R, Del Pizzo J, Sosa R. Adrenal-preserving minimally invasive surgery: The role of laparoscopic partial adrenalectomy, cryosurgery, and radiofrequency ablation of the adrenal gland. Current Urology Reports. 2003; 4(1):87-92. [PubMed: 12537947]

125. Smulders J, de Hingh I, Stavast J, Jackimowicz J. Exploring new technologies to facilitate laparoscopic surgery: creating intestinal anastomoses without sutures or staples, using a radiofrequency-energy-driven bipolar fusion device. Surgical Endoscopy. 2007; 21(11):2105-9. [PubMed: 17514393]

126. Soon PSH, Yeh MW, Sywak MS, Sidhu SB. Use of the Ligasure vessel sealing system in laparoscopic adrenalectomy. ANZ Journal of Surgery. 2006; 76(9):850-2. [PubMed: 16922910]

127. Hope WW, Burns JM, Newcomb WL, Heniford BT, Sing RF. Safety and efficacy of the electrothermal bipolar vessel sealer in trauma. JOURNAL OF ENDOUROLOGY. 2009; 40(5): 564-6.

128. Kimura M, Baba S, Polascik TJ. Minimally invasive surgery using ablative modalities for the localized renal mass. International Journal of Urology. 2010; 17(3):215-27. [PubMed: 20070411]

129. Oefelein MG. Delayed Presentation of Urinoma after Radiofrequency Ablation-Assisted Laparoscopic Partial Nephrectomy. Journal of Endourology. 2006; 20(1):27-30.10.1089/end. 2006.20.27 [PubMed: 16426128]

130. Onishi T, Nishikawa K, Hasegawa Y, et al. Assessment of Health-related Quality of Life after Radiofrequency Ablation or Laparoscopic Surgery for Small Renal Cell Carcinoma: a Prospective Study with Medical Outcomes Study 36-Item Health Survey (SF-36). Jpn J Clin Oncol. 2007; 37(10):750-4. [PubMed: 17942577]

131. Bachellier P, Ayav A, Pai M, Jean-Christopher W, Edoardo R, Daniel J, et al. Laparoscopic liver resection assisted with radiofrequency. American journal of surgery. 2007; 193(4):427-30. [PubMed: 17368282]

132. Hompes D, Aerts R, Penninckx F, Topal B. Laparoscopic liver resection using radiofrequency coagulation. Surgical Endoscopy. 2007; 21(2):175-80. [PubMed: 17122980]

133. Tan BJ, El-Hakim A, Nora M, Yavor S, Arthur S, Benjamin R, LEE. Comparison of laparoscopic saline infused to dry radio frequency ablation of renal tissue: evolution of histological infarct in the porcine model. The Journal of urology. 2004; 172(5):2007-12. [PubMed: 15540779] 
134. Asahina YN, Hiroyuki, Izumi Namiki. Laparoscopic radiofrequency ablation for hepatocellular caecinoma. Digestive Endoscopy. 2009; 21(2):67-72. [PubMed: 19691776]

135. Sadiq TS, Shrestha R, Weeks S, Gerber DA. Laparoscopic radiofrequency ablation provides local control of hepatocellular carcinoma in patients awaiting liver transplant. Journal of the American College of Surgeons. 2004; 199(3):16.

136. van den Bos R, Lidia A, Michael K, Martino N, Tamar N. Endovenous therapies of lower extremity varicosities: A meta-analysis. Journal of vascular surgery : official publication, the Society for Vascular Surgery [and] International Society for Cardiovascular Surgery, North American Chapter. 2009; 49(1):230-9.

137. Weil, L.; Glover, JP.; Weil, LS. A New Minimally Invasive Technique for Treating Plantar Fasciosis Using Bipolar Radiofrequency: A Prospective Analysis. 2008. p. 13-8.

138. Hüscher CGS, Lirici MM, Di Paola M, Crafa F, Napolitano C, Mereu A, et al. Laparoscopic cholecystectomy by ultrasonic dissection without cystic duct and artery ligature. Surgical Endoscopy. 2003; 17(3):442-51. [PubMed: 12399846]

139. Redwan AA. Single-Working-Instrument, Double-Trocar, Clipless Cholecystectomy Using Harmonic Scalpel: A Feasible, Safe, and Less Invasive Technique. Journal of Laparoendoscopic \& Advanced Surgical Techniques. 2010; 20(7):597-603.10.1089/lap.2009.0375 [PubMed: 20629516]

140. Harrell AG, Kercher KW, Heniford BT. Energy Sources in Laparoscopy. Surgical Innovation. 2004; 11(3):201-9.10.1177/107155170401100310

141. Berry SM, Ose KJ, Bell RH, Fink AS. Thermal injury of the posterior duodenum during laparoscopic cholecystectomy. Surgical Endoscopy. 1994; 8(3):197-200. [PubMed: 8191358]

142. Giger U, Michel JM, Vonlanthen R, Becker K, Kocher T, Krähenbühl L. Laparoscopic cholecystectomy in acute cholecystitis: indication, technique, risk and outcome. Langenbeck's Archives of Surgery. 2005; 390(5):373-80.

143. Peters JH, Ellison EC, Innes JT, Liss JL, Nichols KL, Lomano JM, et al. Safety and efficacy of laparoscopic cholecystectomy. A prospective analysis of 100 initial patients. Annals of Surgery. 1991; 213(1):3-12. [PubMed: 1824674]

144. Kandil T, El Nakeeb A, El Hefnawy E. Comparative Study between Clipless Laparoscopic Cholecystectomy by Harmonic Scalpel Versus Conventional Method: A Prospective Randomized Study. Journal of Gastrointestinal Surgery. 2010; 14(2):323-8. [PubMed: 19882194]

145. Tsimoyiannis EC, Jabarin M, Glantzounis G, Lekkas ET, Siakas P, Stefanaki-Nikou S. Laparoscopic Cholecystectomy Using Ultrasonically Activated Coagulating Shears. Surgical Laparoscopy Endoscopy \& Percutaneous Techniques. 1998; 8(6):421-4.

146. Lane GE, Lathrop JC. Comparison of results of KTP/532 laser versus monopolar electrosurgical dissection in laparoscopic cholecystectomy. J Laparoendosc Surg. 1993; 3(3):209-14. [PubMed: 8347872]

147. Bordelon BM, Hobday KA, Hunter JG. Laser vs electrosurgery in laparoscopic cholecystectomy. A prospective randomized trial. Arch Surg. 1993; 128(2):233-6. [PubMed: 8431125]

148. El Nakeeb A, Askar W, El Lithy R, Farid M. Clipless laparoscopic cholecystectomy using the Harmonic scalpel for cirrhotic patients: a prospective randomized study. Surgical Endoscopy. 2010; 24(10):2536-41. [PubMed: 20376490]

149. Amaral JF. Laparoscopic Cholecystectomy in 200 Consecutive Patients using an Ultrasonically Activated Scalpel. Surgical Laparoscopy Endoscopy \& Percutaneous Techniques. 1995; 5(4): 255-62.

150. A Prospective Analysis of 1518 Laparoscopic Cholecystectomies. New England Journal of Medicine. 1991; 324(16):1073-8. \%U http://www.nejm.org/doi/full/10.56/ NEJM199104183241601. [PubMed: 1826143]

151. Kurauchi N, Kamii N, Kazui K, Saji Y, Uchino J. Laparoscopic cholecystectomy: A report on the community hospital experience in Hokkaido. Surgery Today. 1998; 28(7):714-8.10.1007/ bf02484617 [PubMed: 9697264] 
152. Hideki N, Masato N, Norihiro Y, et al. Electrosurgical devices for abdominal surgery: Comparison between monopolar devices and bipolar scissors. Surgical Therapy. 2003; 89(1):813.

153. Mantke R, Halangk W, Habermann A, Peters B, Konrad S, Guenther M, et al. Efficacy and safety of 5-mm-diameter bipolar and ultrasonic shears for cutting carotid arteries of the hybrid pig. Surgical Endoscopy. 2010:1-9.

154. Richter S, Kollmar O, Schilling M, Pistorius G, Menger M. Efficacy and quality of vessel sealing. Surgical Endoscopy. 2006; 20(6):890-4. [PubMed: 16738977]

155. Carbonell AM, Joels CS, Kercher KW, Matthews BD, Sing RF, Heniford BT. A Comparison of Laparoscopic Bipolar Vessel Sealing Devices in the Hemostasis of Small-, Medium-, and LargeSized Arteries. Journal of Laparoendoscopic \& Advanced Surgical Techniques. 2003; 13(6):37780. [PubMed: 14733701]

156. Goldstein SL, Harold KL, Lentzner A, Matthews BD, Kercher KW, Sing RF, et al. Comparison of Thermal Spread after Ureteral Ligation with the Laparo-Sonicâ,, $\notin$ Ultrasonic Shears and the Ligasure $^{\mathrm{TM}}$ System. Journal of Laparoendoscopic \& Advanced Surgical Techniques. 2002; 12(1): 61-3.10.1089/109264202753486957 [PubMed: 11905864]

157. Phillips CK, Hruby GW, Durak E, Lehman DS, Humphrey PA, Mansukhani MM, et al. Tissue Response to Surgical Energy Devices. Urology. 2008; 71(4):744-8. [PubMed: 18289646]

158. Wetter, PA.; Kavic, MS., et al. Prevention \& Management of Laparoendoscopic Surgical Complications. Society of Laparoendoscopic Surgeons; 1999. 
Table 1

Most commonly used energy devices in minimally invasive surgery

\begin{tabular}{|c|c|c|}
\hline Type & \multicolumn{2}{|c|}{ Product Name } \\
\hline \multirow[t]{2}{*}{ Monopolar electrosurgery } & 1 & Opti $^{\mathrm{TM}}$ \\
\hline & 2 & Encision $\mathrm{AEM}^{\mathrm{TM}}$ \\
\hline \multirow[t]{3}{*}{ Bipolar electrosurgery } & $\mathbf{1}$ & LigaSure $^{\mathrm{TM}}$ \\
\hline & 2 & Gyrus PlasmaKinectics ${ }^{\mathrm{TM}}$ \\
\hline & 3 & EnSeal $^{\mathrm{TM}}$ \\
\hline \multirow[t]{5}{*}{ Ultrasonic energy } & $\mathbf{1}$ & Ultracision harmonic scalpel \\
\hline & 2 & Harmonic ACE \\
\hline & 3 & Harmonic FOCUS \\
\hline & 4 & SonoSurg \\
\hline & 5 & AutoSonix \\
\hline \multirow[t]{4}{*}{ Laser energy } & \multicolumn{2}{|c|}{ Most commonly referred to their type than a product name. } \\
\hline & 1 & Nd: YAG laser (neodymium-doped yttrium aluminum garnet) \\
\hline & 2 & argon laser \\
\hline & 3 & $\mathrm{CO}_{2}$ laser \\
\hline \multirow[t]{2}{*}{ Argon beam coagulator } & 1 & System $7550^{\mathrm{TM}} \mathrm{ABC} \circledast$ \\
\hline & 2 & Cardioblate ${ }^{\circledR}$ \\
\hline \multirow[t]{3}{*}{ Radio Frequency (RF) energy } & 1 & RF 3000® Radiofrequency Ablation System \\
\hline & 2 & StarBurst ${ }^{\circledR}$ \\
\hline & 3 & Cardioblate ${ }^{\circledR}$ \\
\hline
\end{tabular}




\begin{tabular}{|c|c|c|c|c|c|c|c|c|c|c|c|}
\hline & 气્ّ & & $\begin{array}{l}\frac{o}{a} \\
\bar{e} \\
\stackrel{e}{=} \\
=\end{array}$ & & & & & & & & \\
\hline & 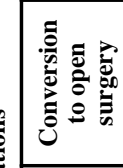 & 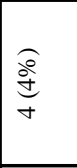 & $\begin{array}{l}0 \\
\delta \\
\infty \\
\infty \\
e \\
y\end{array}$ & & 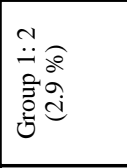 & & & & 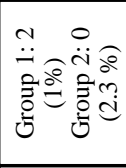 & 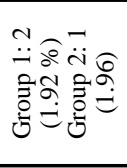 & 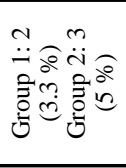 \\
\hline & 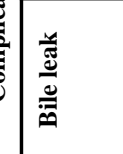 & $\begin{array}{l}\widehat{d} \\
\stackrel{d}{d} \\
\sim\end{array}$ & $\begin{array}{l}a \\
\stackrel{0}{a} \\
\text { d } \\
0 \\
0\end{array}$ & 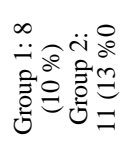 & 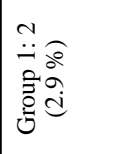 & 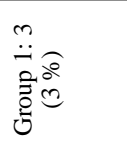 & 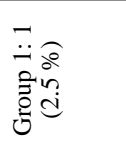 & 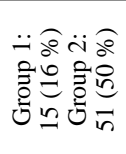 & 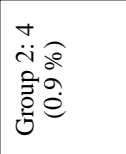 & 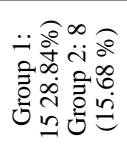 & 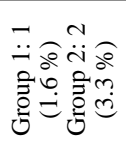 \\
\hline & 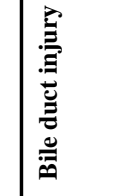 & 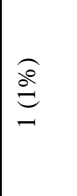 & $\begin{array}{l}\widehat{o} \\
\hat{d} \\
\stackrel{0}{\varrho} \\
-\end{array}$ & & & & & & & & \\
\hline & 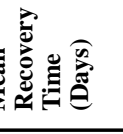 & $\begin{array}{l}\infty \\
0 \\
0 \\
01 \\
\infty \\
\\
\\
\end{array}$ & & & & & & & & & \\
\hline & 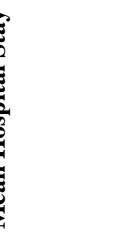 & 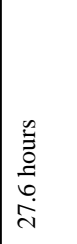 & 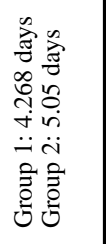 & 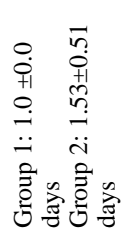 & 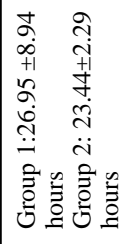 & 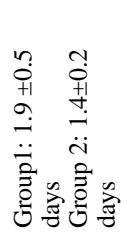 & 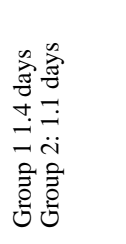 & 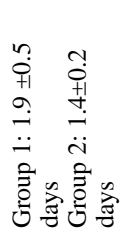 & 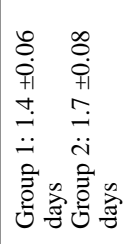 & & \\
\hline & 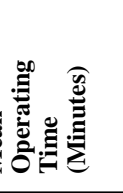 & $\begin{array}{l}0 \\
+ \\
+1 \\
\hat{1} \\
\dot{\infty} \\
\infty\end{array}$ & 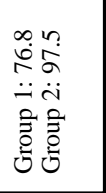 & 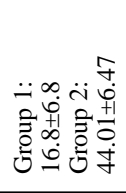 & 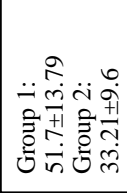 & 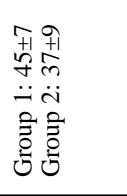 & 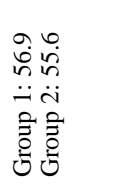 & 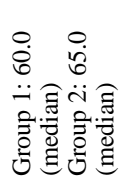 & 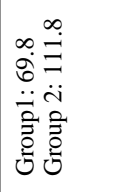 & 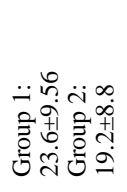 & 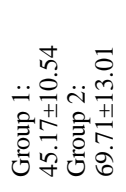 \\
\hline & & 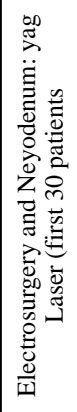 & 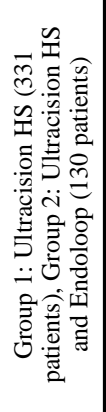 & 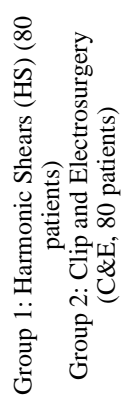 & 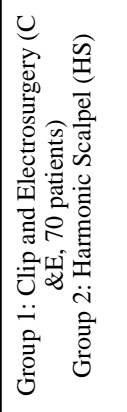 & 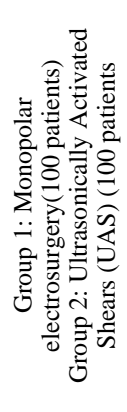 & 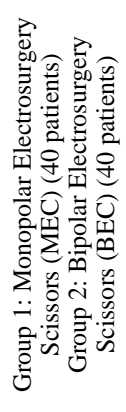 & 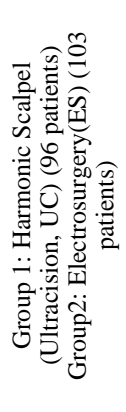 & 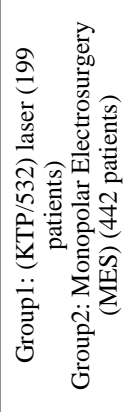 & 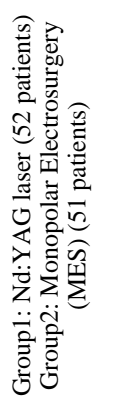 & 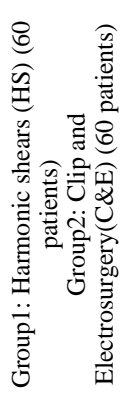 \\
\hline & & 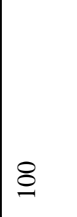 & $\bar{\sigma}$ & $\stackrel{8}{\circ}$ & 导 & 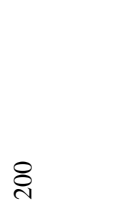 & $\infty$ & ¿્స & $\bar{\sigma}$ & $\stackrel{\tilde{\varrho}}{\underline{\theta}}$ & ปิ \\
\hline & & 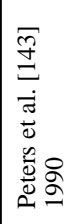 & 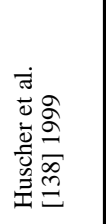 & 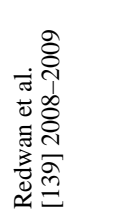 & 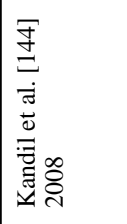 & 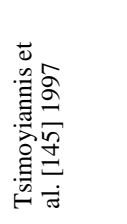 & 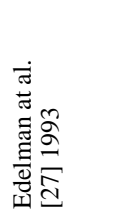 & 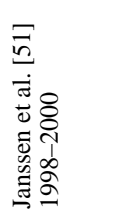 & 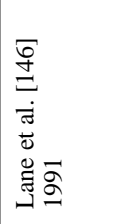 & 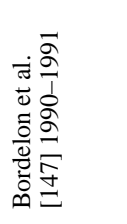 & 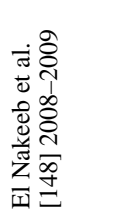 \\
\hline
\end{tabular}

Surg Endosc. Author manuscript; available in PMC 2014 September 01. 


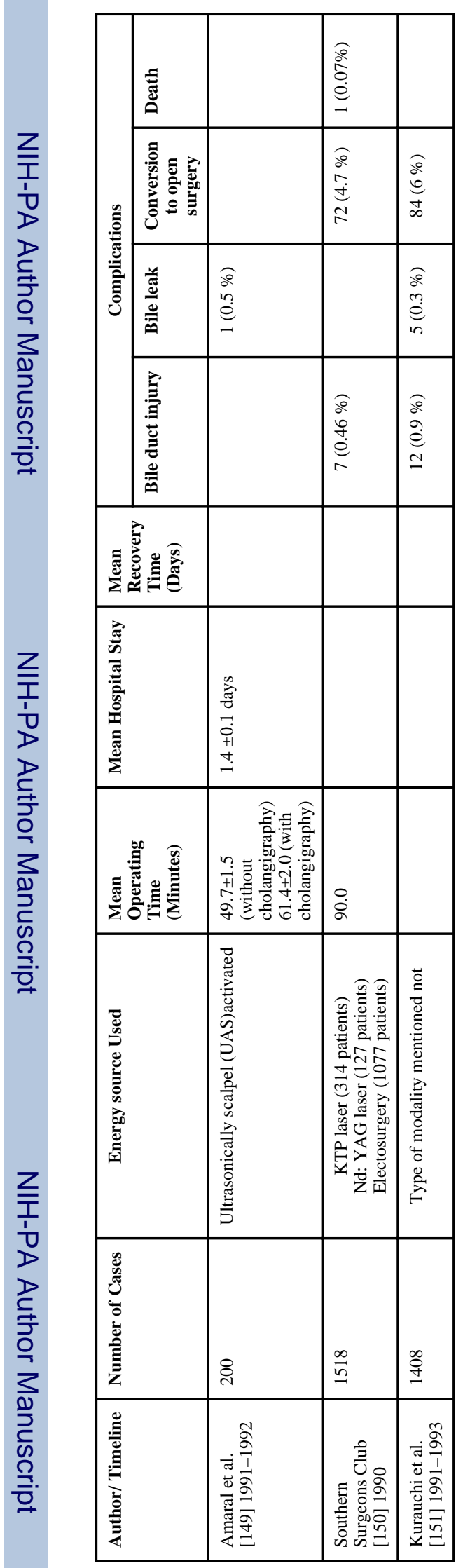

Surg Endosc. Author manuscript; available in PMC 2014 September 01. 
Table 3

General advantages and disadvantages of energy methods

\begin{tabular}{|c|c|c|c|}
\hline \multicolumn{4}{|c|}{ Monopolar Electrosurgery } \\
\hline \multicolumn{2}{|c|}{ Advantages } & \multicolumn{2}{|c|}{ Disadvantages } \\
\hline $\begin{array}{l}1 \\
2 \\
3 \\
4\end{array}$ & $\begin{array}{l}\text { Simple equipment and easy to use. } \\
\text { Cheaper than other energy devices. } \\
\text { Usually results in shorter operative times. } \\
\text { Best method for making simple incisions on the skin } \\
\text { [152] }\end{array}$ & $\begin{array}{l}3 \\
4 \\
5\end{array}$ & $\begin{array}{l}\text { Injury to patients through direct and capacitive coupling, } \\
\text { insulation failure and return electrode burns. } \\
\text { Interference with pacemakers and other equipments during } \\
\text { surgery. } \\
\text { Risk from OR fire. } \\
\text { Production of smoke. } \\
\text { Higher temperatures at the tool tip and longer cool down } \\
\text { times to a safer temperature compared to other energy based } \\
\text { devices [12]. } \\
\text { Large thermal spread. }\end{array}$ \\
\hline \multicolumn{4}{|c|}{ Bipolar Electrosurgery } \\
\hline \multicolumn{2}{|c|}{ Advantages } & \multicolumn{2}{|c|}{ Disadvantages } \\
\hline $\begin{array}{l}1 \\
2\end{array}$ & $\begin{array}{l}\text { Passage of current through only the portion of the } \\
\text { tissue that is operated. } \\
\text { Smaller thermal spread (For example,- EnSeal } \\
\text { produced a thermal spread of only } 1.84 \mathrm{~mm} \text { in medium } \\
\text { sized ( } 4-5 \mathrm{~mm} \text { ) porcine arteries [153]. } \\
\text { Good for coaptive vessel sealing } \\
\text { Bipolar devices produce equal peak temperatures on } \\
\text { different types of tissues with various thickness [10]. } \\
\text { Bipolar devices can be available in many forms etc. - } \\
\text { scissors, forceps, grips }\end{array}$ & 3 & $\begin{array}{l}\text { Operational time is usually longer than monopolar } \\
\text { electrosurgery and not as effective on small blood vessels. } \\
\text { The amount of thermal spread usually depends on the power } \\
\text { setting and the skill level of the user - Ligasure produced } \\
\text { thermal spread in the range of } 0.6 \text { - } 6 \text { mm in porcine organs } \\
\text { [26, 38, 154-157] } \\
\text { Production of smoke. }\end{array}$ \\
\hline \multicolumn{4}{|c|}{ Ultrasonic energy } \\
\hline \multicolumn{2}{|c|}{ Advantages } & \multicolumn{2}{|c|}{ Disadvantages } \\
\hline $\begin{array}{l}1 \\
2 \\
3\end{array}$ & $\begin{array}{l}\text { Ultrasonic energy usually produces the least amount of } \\
\text { thermal spread [42,165]. } \\
\text { No smoke and only mist due to cavitation effect. } \\
\text { Best energy method for sealing small blood vessels } \\
\text { (upto } 2 \mathrm{~mm} \text { in diameter) }[27,42,166] \text {. } \\
\text { Ultrasonic devices (ACE, Wave, CS14C) produced the } \\
\text { best quality seals at lower power levels [153]. } \\
\text { Lesser operating time. }\end{array}$ & 1 & $\begin{array}{l}\text { Produces high blade temperatures and can damage adjacent } \\
\text { tissues or organs when come in contact immediately after } \\
\text { swictched OFF [10]. } \\
\text { Temperature produced is inversely proportional to the tissue } \\
\text { thickness [10]. } \\
\text { Not all devices are the same -the LCS device was shown to } \\
\text { have caused high thermal spread }-8.5 \mathrm{~mm} \text { in porcine veins } \\
\text { [26]. } \\
\text { The high power level settings of ultrasonic devices can } \\
\text { cause significant thermal spread (upto } 25.7 \mathrm{~mm} \text { ) and peak } \\
\text { temperatures (upto } 140^{\circ} \mathrm{C} \text { in porcine organs) [44]. } \\
\text { The ultrasonic devices do not produce effective sealing for } \\
\text { blood vessels over } 2 \mathrm{~mm} \text { in diameter }[26,38] \text {. }\end{array}$ \\
\hline \multicolumn{4}{|c|}{ Laser energy } \\
\hline Advanta & & Disadv & ages \\
\hline 1 & $\begin{array}{l}\text { Can be effective when right laser type and } \\
\text { configuration is chosen. } \\
\text { Most widely used in gynecological procedure because } \\
\text { of precise control of amount and depth of tissues to be } \\
\text { affected, }\end{array}$ & $\begin{array}{l}2 \\
3 \\
4\end{array}$ & $\begin{array}{l}\text { Very expensive equipment. } \\
\text { Risk of OR fire. } \\
\text { Increased operating time in general. } \\
\text { Air embolism which can be fatal. }\end{array}$ \\
\hline
\end{tabular}

Surg Endosc. Author manuscript; available in PMC 2014 September 01. 


\begin{tabular}{|c|c|c|c|}
\hline \multicolumn{4}{|c|}{ Monopolar Electrosurgery } \\
\hline Advantages & Disadvantages \\
\hline $\mathbf{3} \quad$ Less scarring compared to other modes of energy. & $\mathbf{5}$ & $\begin{array}{l}\text { Either the precision or efficiency of the laser has to be } \\
\text { compromised - one of them is usually sacrificed [158]. }\end{array}$ \\
\hline \multicolumn{2}{|c|}{ Argon Beam coagulation } \\
\hline Advantages & Disadvantages \\
\hline $\mathbf{1}$ & $\begin{array}{l}\text { Most effective form of hemostasis and is used in } \\
\text { procedures involving major blood loss [92, 105, 109]. }\end{array}$ & $\begin{array}{l}\text { The high efficiency of ABC also translates to faster } \\
\text { coagulation times. }\end{array}$ \\
$\mathbf{3} \quad \begin{array}{l}\text { Argon gas blows away blood and debris from the } \\
\text { surgical field and produces a coagulated surface that is } \\
\text { more uniform. }\end{array}$ & $\mathbf{1}$ & $\begin{array}{l}\text { The major drawback of ABC is argon gas embolism which } \\
\text { is a result of the insolubility of argon gas in blood. This has } \\
\text { resulted in cardiac arrests and even death [93, 94, 96]. }\end{array}$ \\
$\mathbf{4}$ & $\begin{array}{l}\text { ABC produces less smoke than conventional } \\
\text { electrosurgery. }\end{array}$ \\
$\mathbf{5} \quad \begin{array}{l}\text { It has shown that the thermal spread of the ABC } \\
\text { system is constant (2-3 mm) [140]. }\end{array}$ & $\begin{array}{l}\text { Involves the use of electricity, hence the risk of interference } \\
\text { with surgical equipment exists. }\end{array}$ \\
\hline
\end{tabular}


Table 4

Deaths due to laparoscopic use of energy sources

\begin{tabular}{|c|c|c|}
\hline Author & Energy source & Description \\
\hline $\begin{array}{l}\text { Peterson et al. (1981) } \\
{[16]}\end{array}$ & Electrosurgery & $\begin{array}{l}\text { Deaths of two women in } 1978 \text { and } 1979 \text { due to the damage to the bowel during the } \\
\text { laparoscopic sterilization procedure using monopolar electrocoagulation. The complications } \\
\text { were post-operative. }\end{array}$ \\
\hline $\begin{array}{l}\text { Willson et al. (1994) } \\
{[175]}\end{array}$ & Electrosurgery & $\begin{array}{l}\text { Death due to thermal injury to the colon occurring beyond the field of view during } \\
\text { laparoscopic cholecystectomy. }\end{array}$ \\
\hline Curro et al. (2005) [47] & Harmonic Scalpel & $\begin{array}{l}\text { Death of two patients (one with severe liver failure and one with sepsis) due to the failure of } \\
\text { laparoscopic cholecystectomy in treatment of Child Pugh C cirrhosis using the harmonic } \\
\text { scalpel. The result is more of the case of ineffective procedure rather than a surgical } \\
\text { complication. }\end{array}$ \\
\hline $\begin{array}{l}\text { Tellides et al. (1998) } \\
\text { [69] }\end{array}$ & Laser & $\begin{array}{l}\text { Death of two patients with embolic cardiac and neurologic complications after bronchoscopic } \\
\text { Nd: YAG laser tumor ablation. The embolism was caused due to the use of laser fiber air } \\
\text { coolant at high flow. }\end{array}$ \\
\hline $\begin{array}{l}\text { Baggish et al. (1989) } \\
{[66]}\end{array}$ & Laser & $\begin{array}{l}\text { Death of two patients due to venous embolization leading to cardiovascular collapose while } \\
\text { undergoing intrauterine surgery with the Nd:YAG laser delivered by the artificial sapphire tip. } \\
\text { Use of sapphire tip and gas cooling was stated as the reason }\end{array}$ \\
\hline $\begin{array}{l}\text { Challener et al. (1990) } \\
\quad[67]\end{array}$ & Laser & $\begin{array}{l}\text { Death of one patient due to venous air embolism while undergoing laser endometrial ablation } \\
\text { with the sheathed quartz fiber Nd: YAG laser. The embolism was caused by the entry of } \\
\text { compressed air to the endometrical cavity while reinserting the hysteroscope }\end{array}$ \\
\hline $\begin{array}{l}\text { Schroder et al. (1989) } \\
{[76]}\end{array}$ & Laser & $\begin{array}{l}\text { Death of one patient due to air embolism while undergoing laser thermia with the Nd:YAG } \\
\text { laser delivered by artificial sapphire tip. Coaxial air flow for cooling was stated as the reason }\end{array}$ \\
\hline Yuan et al. (1993) [73] & Laser & $\begin{array}{l}\text { Death of one patient due to venous gas embolism while undergoing bilateral choanal stenosis } \\
\text { with the Nd:YAG laser delivered by artificial sapphire tip. Coxial cooling system with } \mathrm{N}_{2} \text { gas } \\
\text { was stated as the reason }\end{array}$ \\
\hline $\begin{array}{l}\text { Peachy et al. (1988) } \\
\text { [71] }\end{array}$ & Laser & $\begin{array}{l}\text { Death of one patient due to systemic air embolism while undergoing resection of a bronchial } \\
\text { carcinoma with Nd:YAG laser. }\end{array}$ \\
\hline Lang et al. (1991) [69] & Laser & $\begin{array}{l}\text { Death of one patient due to postoperative myocardial infarction because of air embolism while } \\
\text { undergoing treatment for endobronchial carcinoma with Nd:YAG laser }\end{array}$ \\
\hline $\begin{array}{l}\text { Sezeur et al. (2008) } \\
\quad[97]\end{array}$ & $\mathrm{ABC}$ & $\begin{array}{l}\text { The death of a } 20 \text { year old man undergoing laparoscopic partial splenectomy for the removal } \\
\text { of a benign cyst. }\end{array}$ \\
\hline $\begin{array}{l}\text { ECRI report. (1994) } \\
{[98]}\end{array}$ & $\mathrm{ABC}$ & $\begin{array}{l}\text { Death of one patient from complications of a gas embolism caused by intra-abdominal } \\
\text { overpressurization during a laparoscopic cholecystectomy. }\end{array}$ \\
\hline $\begin{array}{l}\text { Ousmane at al. (2002) } \\
{[\text { [99] }}\end{array}$ & $\mathrm{ABC}$ & Death of one patient from complications of a gas embolism during liver surgery \\
\hline
\end{tabular}

